\title{
Photang thrust sheet: an accretionary complex structurally below the Spontang ophiolite constraining timing and tectonic environment of ophiolite obduction, Ladakh Himalaya, NW India
}

\author{
RICHARD I. CORFIELD, MIKE P. SEARLE \& OWEN R. GREEN \\ Department of Earth Sciences, Oxford University, Parks Road, Oxford OX1 3PR, UK \\ (e-mail:mikes@earth.ox.ac.uk)
}

\begin{abstract}
The pre-collisional tectonic evolution of the north Indian continental margin is best recorded in the few ophiolite complexes preserved, the largest of which occurs in the Spontang area of the Himalayas. Structural, sedimentological, palaeontological and geochemical work on the ophiolite and associated allochthonous thrust sheets has been carried out to constrain the timing and tectonic environment of ophiolite obduction. A distinct thrust sheet of accretionary complex rocks has been identified immediately underlying the ophiolite. Accreted units include thrust slices of tectonic melanges and alkaline basaltic lavas capped by limestones ranging from late Permian to late Cretaceous in age, interpreted as remnants of former seamounts. The accretionary complex formed above a north dipping intra-oceanic subduction zone during the Cretaceous, the Spontang ophiolite located in the hanging wall. Beneath the Photang thrust sheet, two further distinct, allochthonous thrust sheets of sedimentary melanges and continental slope deposits have been recognized. The structural relations of the allochthonous thrust sheets with the sediments of the north Indian margin have been mapped in detail and show clear evidence that obduction occurred in the late Cretaceous. At this time the Dras-Kohistan intra-oceanic arc had already collided with the southern Asian margin, over $1500 \mathrm{~km}$ to the north. Obduction of the Spontang ophiolite therefore records a separate tectonic episode in the Ladakh Himalaya.
\end{abstract}

Keywords: Himalayas, Tethys, Late Cretaceous, ophiolite, obduction.

The Spontang ophiolite complex in the Ladakh Himalaya lies c. $30 \mathrm{~km}$ south of the Indus suture zone, which marks the boundary between the Indian and Asian plates (Reuber 1986; Searle 1986; Searle et al. 1988). The complex tectonically overlies the passive margin sediments of the north Indian plate margin and consists of Neo-Tethyan oceanic crust (Spontang ophiolite) and associated Neo-Tethyan allochthonous thrust sheets. The Spontang ophiolite complex is one of the few preserved ophiolite complexes in the Himalayan orogenic belt (Gansser 1964). Work on ophiolites complexes from the western end of the orogen in western Pakistan indicates that obduction occurred during the late Cretaceous to Paleocene, prior to the collision of India with Asia (Allemann 1979; Moores et al. 1980; Beck et al. 1995, 1996; Gnos et al. 1997). An understanding of the tectonic evolution of the Spontang ophiolite complex is very important in determining the pre-Himalayan collision tectonics of Neo-Tethys east of the Pakistan ophiolites.

The Spontang ophiolite has been the subject of several reconnaissance studies within the broader context of the Ladakh Himalaya (Fuchs 1977, 1979; Srikantia \& Razdan 1981; Searle 1983; Searle 1986; Keleman \& Sonnenfeld 1983). More recently, detailed studies were published on the petrology of the ophiolite (Reuber 1986), the associated melanges (Reuber et al. 1992) and the regional structure (Searle et al. 1997), with an emphasis on constraining the timing of ophiolite obduction. Fuchs (1979, 1982), Keleman \& Sonnenfeld (1983), Reuber (1986), Colchen \& Reuber (1986), Colchen et al. (1986, 1987), Garzanti et al. (1987), Keleman et al. (1988), Fuchs \& Willems (1990) and Reuber et al. (1992) all suggested a post-early Eocene age of obduction because the Spontang ophiolite has been thrust over Palaeocene-early
Eocene limestones. Searle (1983, 1986), Searle et al. (1988), Searle et al. (1997) and Corfield \& Searle (in press), proposed that this thrust was a younger structure which re-stacked the earlier thrust pile during the Himalayan collision and that the obduction event occurred in the late Cretaceous-early Palaeocene.

This paper deals primarily with the Photang thrust sheet, an accretionary complex immediately beneath the Spontang ophiolite. Other Neo-Tethyan allochthonous thrust sheets belonging to the Spontang ophiolite complex, comprised of continental slope deposits (Lamayuru Complex) and obduction related platform collapse deposits (Photok Unit) are also described. We present here new mapping together with structural, sedimentological, palaeontological and geochemical data. These data are used to discuss the probable timing and tectonic setting of obduction of the Spontang ophiolite complex.

\section{Geological setting}

The mountains of the Ladakh and Zanskar ranges in NW India (Fig. 1), expose rocks of the southern Asian margin, the Indus Suture Zone and the northern Indian continental margin (Searle 1986; Searle et al. 1988, 1997; Gaetani \& Garzanti 1991; Robertson \& Degnan 1993). The suture zone consists of four distinct tectonic units and has been described and interpreted by Thakur (1981), Brookfield \& Andrews-Speed (1984), Garzanti \& Van Haver (1988) and Searle et al. (1990). Postcollisional clastic rocks of the Indus molasse form the northern edge of the Indus suture zone, unconformably overlying the granitoids of the Ladakh batholith of the Asian plate. Late 


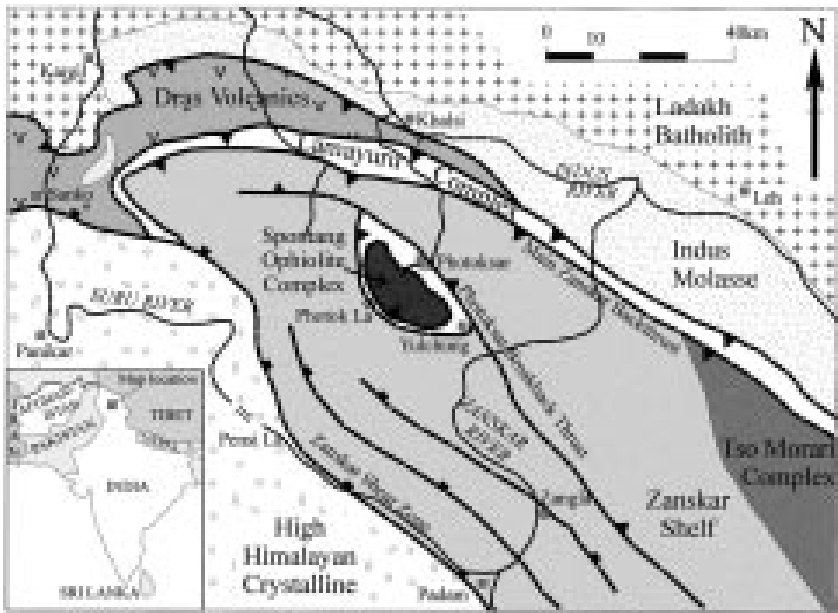

Fig. 1. Map of the major structural features of the Ladakh-Zanskar Himalaya of NW India after Searle (1983, 1986). Figure 2 is located around the region of Photoksar village and Fig. 7 around Yulchung village.

Tertiary back-thrusting has emplaced Jurassic to Cretaceous island-arc volcanic rocks (Dras arc), northwards over the Indus molasse. In the region north of the Spontang ophiolite only the forearc volcaniclastic sediments (Nindam formation) of the Dras arc are exposed (Robertson \& Degnan 1994). Thin zones of ophiolitic melanges mark the northern and southern margins of the Dras island-arc. Deep water deposits of the Lamayuru Complex, preserving slope to base of slope settings of the north Indian passive margin (Robertson \& Degnan 1993) are exposed along the southern margin of the Indus suture zone. The structure of the whole Indus suture zone is dominated by late Tertiary north or north-east vergent folds and thrusts (Searle et al. 1990; Corfield \& Searle in press), the Main Zanskar back-thrust placing Mesozoic shelf carbonates northwards over the Indus suture zone rocks along its southern edge (Fig. 1). The stratigraphy of the Mesozoic and early Tertiary sediments of the northern Indian continental margin has been investigated in some detail (Fuchs 1982; Baud et al. 1984; Garzanti et al. 1987; Gaetani \& Garzanti 1991). The whole sequence has been complexly deformed by folding and thrusting, during both pre-collision obduction-related thrusting and post-collision thrusting processes (Searle 1986; Corfield \& Searle in press). The late Tertiary Photoksar break-back thrust (Figs $1 \& 2$ ) marks the northern extent of exposure of the Spontang ophiolite complex, which is preserved in its hanging wall. The present position of the leading edge of the Spontang ophiolite complex still exposed is approximately $30 \mathrm{~km}$ south of the Indus Suture Zone. However, restoration of a balanced cross-section perpendicular to the regional structure provides a minimum estimate of $85 \mathrm{~km}$ for the displacement of the ophiolite complex onto

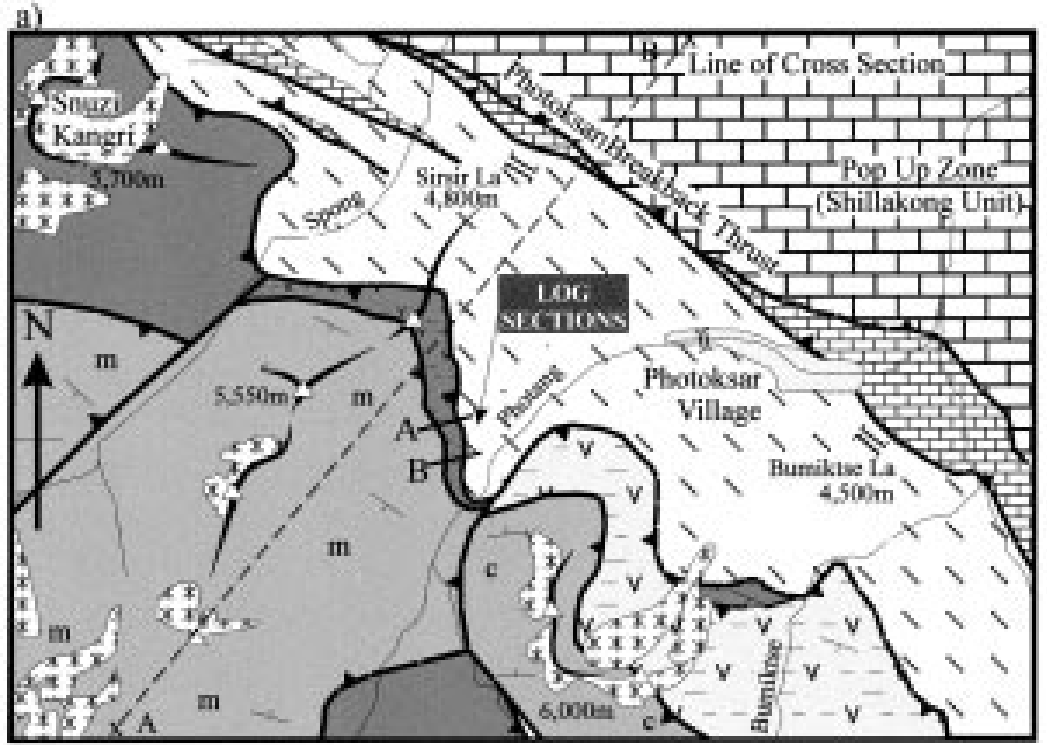

Scale

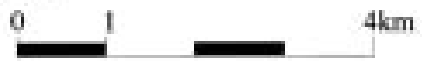

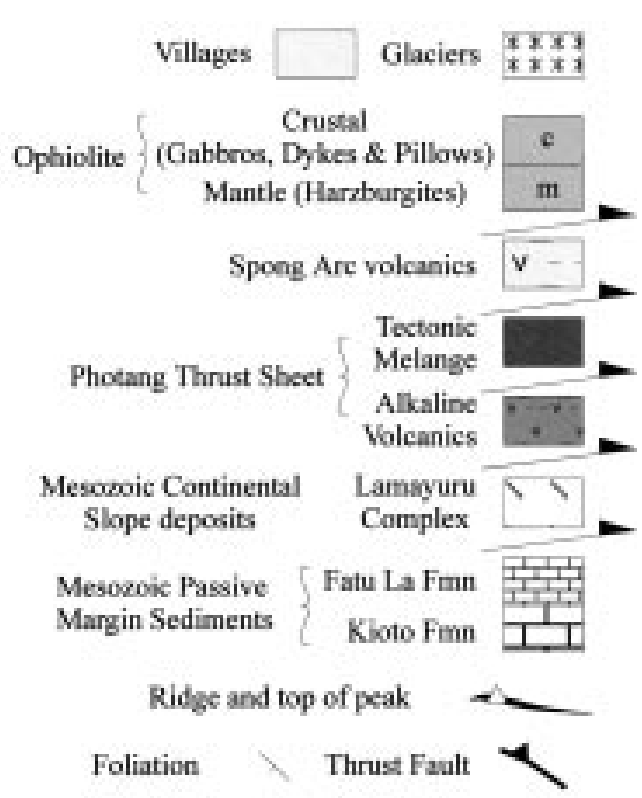

NE

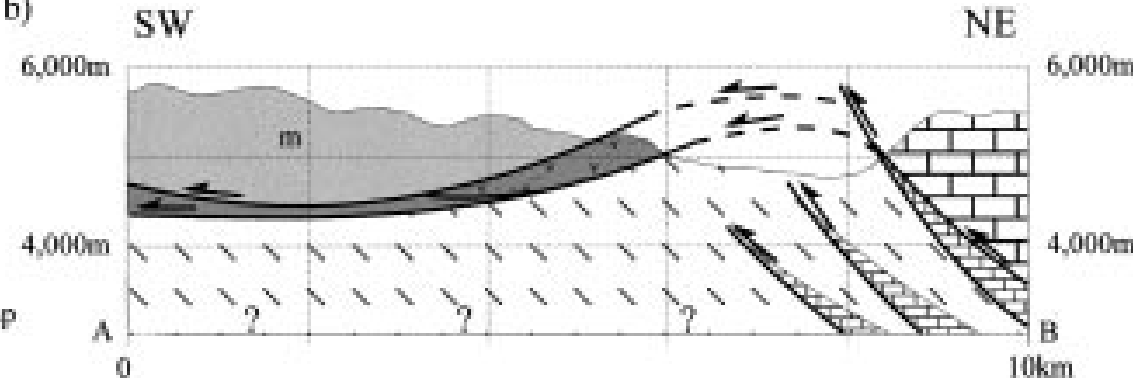

Fig. 2. (a) Map of the area surrounding Photoksar village on the northern edge of the Spontang Ophiolite complex. $\times-\times$ marks the line of section in Fig. 2b. (b) Cross-section through the northern edge of Photang thrust sheet. 
the north Indian continental margin (Corfield \& Searle in press).

\section{Spontang ophiolite}

The Spontang ophiolite contains all the components of a classic ophiolite including upper mantle depleted harzburgites and dunites, lower crustal cumulate gabbros and peridotites (Reuber 1986) and upper crustal sheeted dykes, pillow lavas and oceanic sediments. However, the sequence is tectonically disturbed and much of the crustal section is deformed and difficult to identify in the field. Pillow lavas are abundant and sometimes seen in association with sheeted dykes. Sheeted dykes have only been identified in a highly tectonized state, disrupted by a pervasive network of small-scale faulting and folding. Characteristic basalt-basalt and gabbro-basalt intrusive relationships have been identified in some exposures. Isotropic gabbros have been identified at the base of the sheeted-dyke sequence associated with the basaltic dykes. Massive gabbros and layered gabbros appear to be absent in the preserved ophiolite. Highly serpentinized ultramafic cumulates with poorly developed layering have been identified in separate localities. Nowhere is a continuous section through the Moho exposed and the original structure of the lower crust of the ophiolite is poorly known. Harzburgites form the main constituent of the preserved ophiolite, differentiated into upper pyroxene-rich and lower pyroxene-depleted units (Reuber 1986). The full ophiolite sequence is significantly dismembered by faulting, and the maximum exposed vertical thickness of the deformed ophiolite is $1 \mathrm{~km}$.

A U-Pb zircon date of $174 \pm 2 \mathrm{Ma}$ from high level plagiogranitic melt segregations within the sheeted dykes provide the best estimate for the timing of formation of the ophiolite (Pedersen, Corfield \& Serle, in prep.). The other existing age estimates for the Spontang ophiolite were derived by $\mathrm{K}-\mathrm{Ar}$ dating of amphiboles (Reuber et al. 1989). In this work ages were determined from pegmatitic gabbro dykes $(124 \pm 75$ to $156 \pm 11 \mathrm{Ma})$, 'diabase' dykes $(133 \pm 10$ to $231 \pm 23 \mathrm{Ma})$, a meta-chert $(178 \pm 12 \mathrm{Ma})$ and an amphibolite $(135 \pm 4 \mathrm{Ma})$. Despite the considerable spread in ages and uncertainties these data have been used to infer an intraoceanic thrusting event affecting the Spontang ophiolite at 125-135 Ma (Reuber et al. 1989).

South of Photoksar the ophiolitic rocks are thrust over volcanic rocks and volcaniclastics that crop out all around the northeastern side of the Spontang ophiolite. This sequence, from which a U-Pb zircon date of $91 \pm 3 \mathrm{Ma}$ has been obtained for a dacite, is interpreted to have formed in an island-arc setting (Spong arc) above the oceanic basement of the Spontang ophiolite (Pedersen, Corfield \& Serle, in prep.).

Metamorphic sole rocks characterized by an inverted metamorphic gradient immediately beneath many well studied ophiolites have provided vital evidence in understanding the obduction history. Typically the highest grade rocks in this metamorphic sole are amphibolites, which can be dated radiometrically. In addition the obtained pressure and temperature conditions of metamorphism can provide an important constraint on possible obduction mechanisms. Rare blocks of amphibolite have been reported from the tectonic melanges of the Photang thrust sheet (Searle 1983; Reuber et al. 1989). The latter published a $\mathrm{K}-\mathrm{Ar}$ date on a green amphibole of $135 \pm 4$ Ma from a metamorphic sole which was interpreted as dating the metamorphic formation of amphibole related to intra-oceanic thrusting. However, detailed re-mapping along the base of the ophiolite did not identify any metamorphic sole rocks.

\section{Photang thrust sheet}

Immediately beneath the rocks of the Spontang ophiolite and Spong arc we have recognized a distinct thrust sheet consisting of tectonic melanges and distinct volcanic units associated with oceanic sediments. The Photang thrust sheet is continuous beneath the whole of the western side of the ophiolite, its thickness varying from $300 \mathrm{~m}$ in the lower Photang valley up to $800 \mathrm{~m}$ in the mountain of Snuzi Kangri at its western edge. The large-scale structure of the Photang thrust sheet and the Spontang ophiolite above it, is that of a gentle NW-SEtrending synform in the hanging wall of the SW-vergent Photoksar break-back thrust (Figs 1 \& 22).

\section{Photang valley sections}

The $\mathrm{N}-\mathrm{S}$ ridge separating the Photang and Spong valleys, approximately $5 \mathrm{~km}$ to the west of Photoksar, reaches over $5500 \mathrm{~m}$ and exposes an excellent structural section through the Photang thrust sheet (Fig. 2a \& b). The top of the thrust sheet is marked by a fuchsite-bearing mylonite, separating serpentinized harzburgites above, from the lavas and carbonates of the thrust sheet below. The thrust is almost planar feature with an approximate dip of $25^{\circ} \mathrm{SE}$ in the exposed section, the characteristic orange weathered colour of the mylonites making it readily identifiable in the field. The basal thrust is less exposed, but can be constrained to within $10 \mathrm{~m}$ or less where basaltic volcanic rocks of the Photang thrust sheet crop out above shales of the continental slope deposits of the underlying thrust sheet. Together these major thrusts define a gently southeast-dipping, 300-500 m thick thrust sheet in this region (Fig. 3). Exposures and accessibility are best on the NW side of the Photang valley where two detailed sections through the thrust sheet have been studied (Figs 2, 4 \& 5). The alkaline volcanic rocks and interbedded exotic limestones which comprise the Photang thrust sheet in this region have previously been interpreted as a massive olistolith within a melange deposit (Bassoullet et al. 1978, 1980b; Colchen et al. 1987; Reuber et al. 1992). These previously published descriptions are re-interpreted in the context of the Photang thrust sheet.

A basal thrust zone is recognizable at the foot of each section. In Section A the outcrop has a brecciated appearance with zones of intense deformation surrounding more intact carbonate, sandstone and basaltic bodies. Several metres upwards from the base, the intensity of deformation drops off rapidly and a relatively intact succession of altered basalts follow. Section B exhibits scattered exposures of calc-mylonites below the cliff face within which less deformed blocks of fine grained pelagic limestone dominated by poorly preserved planktonic foramanifera are preserved. We have recognized Globotruncanita stuartiformis (biconvex test, no keel, with triangular chamber, Santonian-Upper Maastrichtian), Globotruncanita subspinosa (no keel, crescent shaped chamber, Campanian-Maastrichtian), Globotruncana ventricosa (two well-developed keels, strongly inflated umbilical side, Campanian-Maastrichtian), Globotruncana arca (Plano-convex double keeled, triangular shaped chamber, Santonian-Maastrichtian) and the upper Campanian zone 


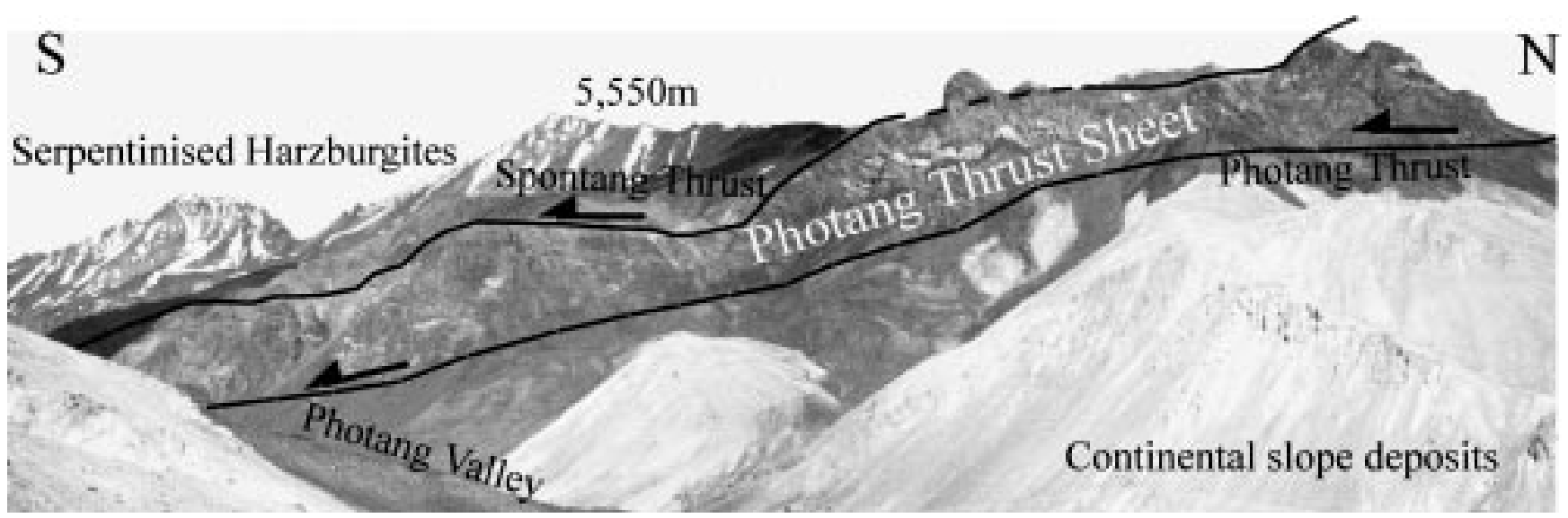

Fig. 3. View of the Photang thrust sheet from the village of Photoksar looking west to the Photang valley. The major thrusts at the base of the mantle sequence (Spontang thrust) and at the base of the accretionary complex (Photang thrust) are shown. Beneath the Photang thrust, the youngest sediments exposed are late Cretaceous shales correlated with the Lamayuru Complex. The logged sections of Figs $4 \& 5$ are located at the left hand edge of the view. Approximate field of view $2.5 \mathrm{~km}$ at thrust sheet, $1.5 \mathrm{~km}$ vertical relief.

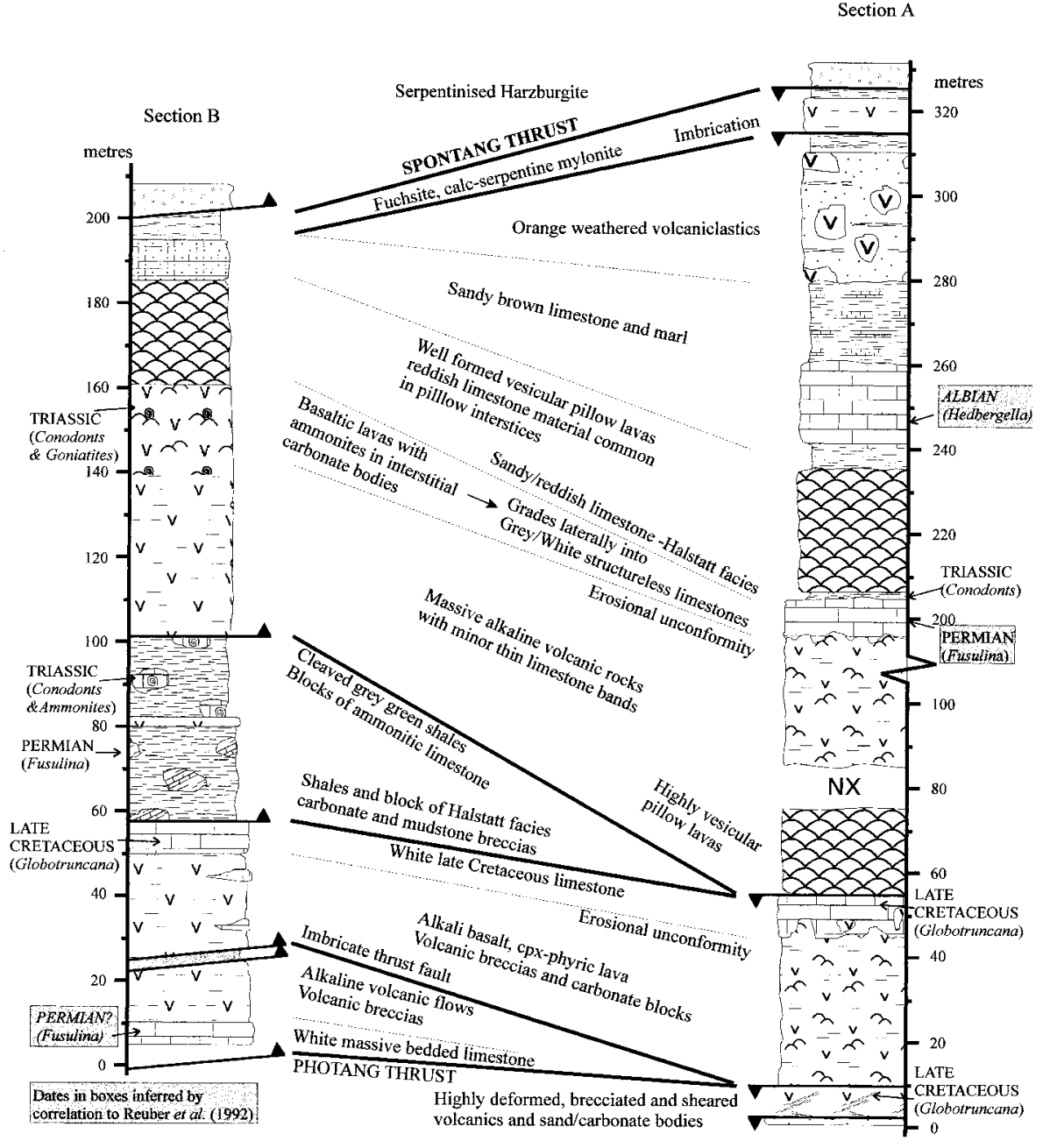

Fig. 4. Logged sections, A and B, through the thrust sheet south of Photoksar, marked on Fig. 2a.

Correlated horizons between sections are marked by dotted lines, thrust surfaces are correlated by full, heavy lines. Views of the sections are shown in Fig. 5. fossil Globotruncanita calcarata (plano-convex test, spines on the outer chambers, Fig. 6g). These foraminifera clearly date the pelagic limestones as Campanian in age. This is consistent with Reuber et al. (1992) who have dated 'calc-schists' from this deformed unit as Senonian (late Cretaceous), on the recognition of Globotruncana arca. We interpret this zone of deformation as arising from thrusting of the accretionary complex over the youngest continental slope sediments deposited in advance of the deformation front. The biostratigraphic results suggest that initial movement along the Photang thrust, over the northern Indian continental slope, took place in the late Cretaceous. In Section B, $25 \mathrm{~m}$ above the 
a)

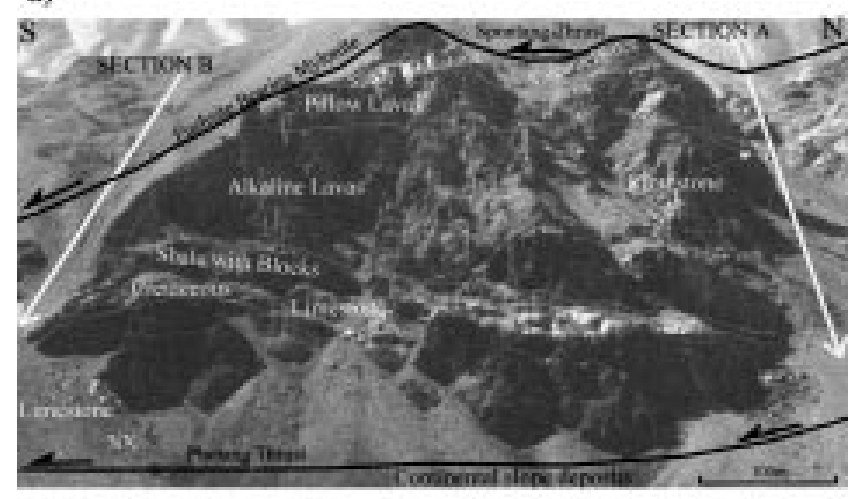

b)

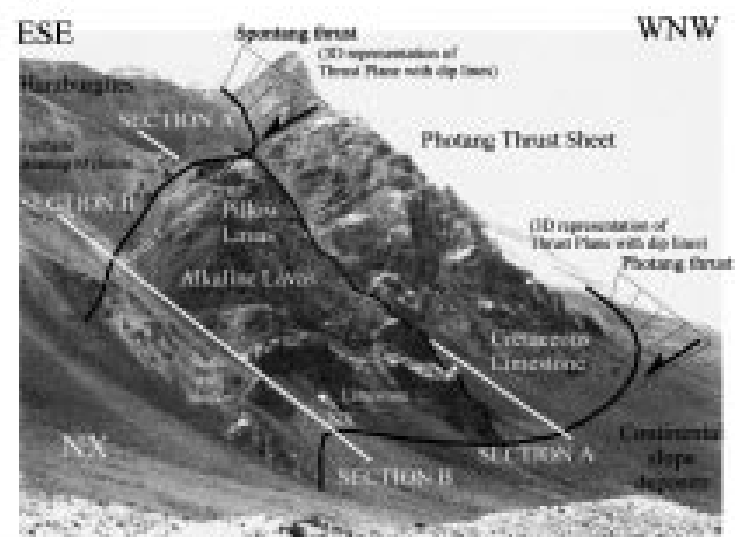

Fig. 5. Views of the alkaline volcanic sections of the Photang thrust sheet (logged sections and major correlations from Fig. 4 are located) (a) View north down the NW side of the Photang valley; (b) view perpendicular to (a) showing the correlations between logged sections.

base, an imbricate thrust partially repeats the sequence, bringing calc-mylonites from the basal thrust zone over alkaline volcanic rocks (Figs 4 \& 6e). These mylonites once again contain intact blocks preserving a similar assemblage of poorly preserved Campanian foraminifera.

Above the basal thrust zone in section B, a massive bedded micritic limestone exhibiting many cross-cutting iron-rich calcitic veins is encountered (Figs $4 \& 6 \mathrm{~d}$ ). Although no fossils were found within this unit, it may correlate with the limestones found by Reuber et al. (1992) at the base of their section within the alkaline volcanic rocks, dated as Upper Permian by the presence of the larger benthic fusulinid foraminifer, Colaniella parva (Fig. 4). The lavas overlying the basal limestone show an intrusive contact possibly reflecting limited consolidation in the sediments at the time of eruption. Within these volcanic rocks, structureless limestone lenses are common which may once again correlate with similar occurrences dated as Permian by Reuber et al. (1992). No such massive limestone is found at the base of Section A, only a sequence of deformed volcanic rocks, often brecciated, similar to those above the limestone in Section B. The biotite and clinopyroxene phyric lavas are typically hydrothermally altered and weathered to a brownish colour, the alkaline character clear from their immobile element geochemistry, discussed later.

At approximately $50 \mathrm{~m}$ in each section a fine-grained limestone overlies the volcanic rocks with an erosional contact, infilling fractures in the underlying lavas. This limestone is clearly seen as a light-coloured band across the outcrop between each section on Fig. 4. The limestone shows a high degree of deformation being cross-cut by numerous low angle shear zones and suffering considerable calcite veining. The matrix supports $10-15 \%$ of poorly preserved planktonic foraminifera and small biserial and planispiral benthic forms, with chambers reaching $0.1 \mathrm{~mm}$ in diameter. We have identified double keeled Globotruncana sp. indicating a Late Cretaceous age.

Unconformably overlying the late Cretaceous limestone is a tectonic melange with a shaly matrix containing blocks of 'Halstatt' facies carbonate, volcanic rocks and mudstone breccias. This unit is around $40 \mathrm{~m}$ thick in Section B but pinches out rapidly to the north (Fig. 5) and is not encountered in Section A. The limestone blocks contain crinoid stems, bivalves, goniatites and fusulinid foraminifera (Fig. 6f) which have been dated as late Permian. A shaly bioclastic limestone horizon from a block several metres in diameter produced a mixed micro-vertebrate assemblage consistent with a near shore environment. The assemblage includes fragments of actinopterygii bony fish and a well preserved sharks tooth, possibly of the genus Orodus. Of considerably more biostratigraphic value is a small assemblage of euconodonts, dominated by ramiform (blade and bar) elements (Fig. 6h). Initial SEM morphological observations suggest these taxa are of the genus Metapolygnathus spp. (Fig. 6h), ornamentation showing similarities with $M$. nodosus or $M$. primitius and an unsculptured form showing similarities with $M$. polygnathiformis (identifications by $\mathrm{M}$. Orchard and I. Sansom). Although continued SEM observations are required to support these preliminary identifications a Late Triassic age is very likely (Upper Carnian to basal Norian). The elements are pitted and granular in appearance and black in colour (although translucent at the denticle tips) with a vitreous lustre suggesting a colour alteration index of 5, >95\% carbon in composition (Epstein et al. 1977) and that the assemblage has been subjected to temperatures in excess of $300^{\circ} \mathrm{C}$.

A thick sequence of alkaline volcanic rocks is thrust over this melange (at $55 \mathrm{~m}$ in Section A) reaches over $100 \mathrm{~m}$ thick and consist predominantly of biotite and clinopyroxene phyric basaltic lavas and pillow lavas. This section is capped by a distinct $7 \mathrm{~m}$ thick structureless white limestone followed by a sandy red 'Halstatt' facies limestone. Further to the south the same horizon is more chaotic with blocks of limestone scattered throughout the volcanic rocks, often containing goniatite fragments (Fig. $6 \mathrm{~b} \& \mathrm{c}$ ). Commonly the goniatites are preserved in tiny lenses of carbonate material between successive lava flows. In some cases a cast of the goniatites has been left within the lava itself. These limestones are probably Permo-Triassic in age and we tentatively correlate them with the Permian limestone of Reuber et al. (1992).

These limestones are succeeded conformably by $25 \mathrm{~m}$ of very well-developed alkaline pillow lavas (Fig. 6a) across the whole exposure, with sandy Halstatt facies limestone commonly found in the interstices of the pillow lavas. This succession would also appear to correlate well with the Carnian limestone of Bassoullet et al. (1980b), found further to the west where they also report $100 \mathrm{~m}$ of pillow lavas. Above the pillow lavas fine-grained siliceous siltstones grade into thinly bedded sandy limestones varying in thickness from $7 \mathrm{~m}$ to $25 \mathrm{~m}$ across sections. These possibly correlate with a unit dated by Reuber et al. (1992) as Albian by the presence of radiolaria, and the planktonic foraminifera identified as Hedbergella sp. We have 
a

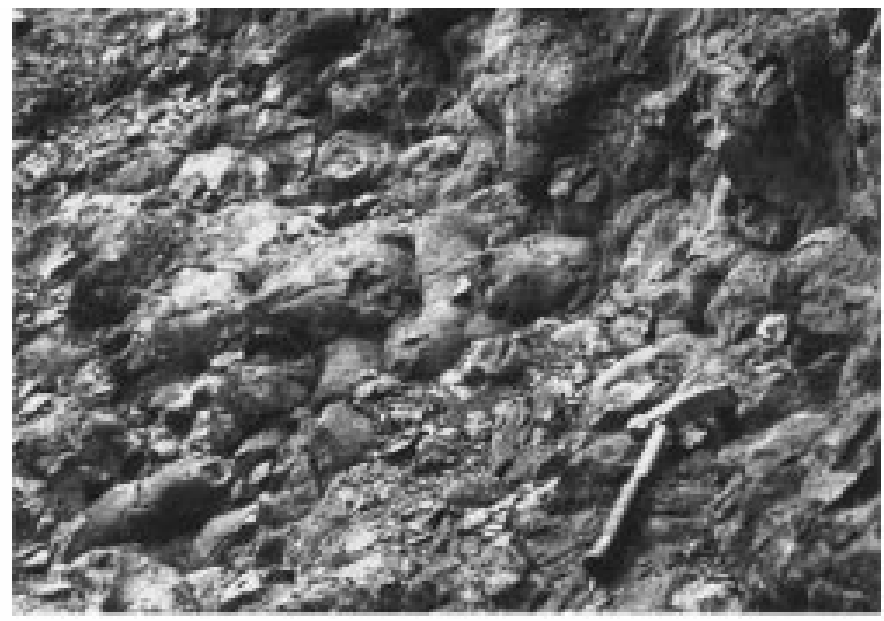

b

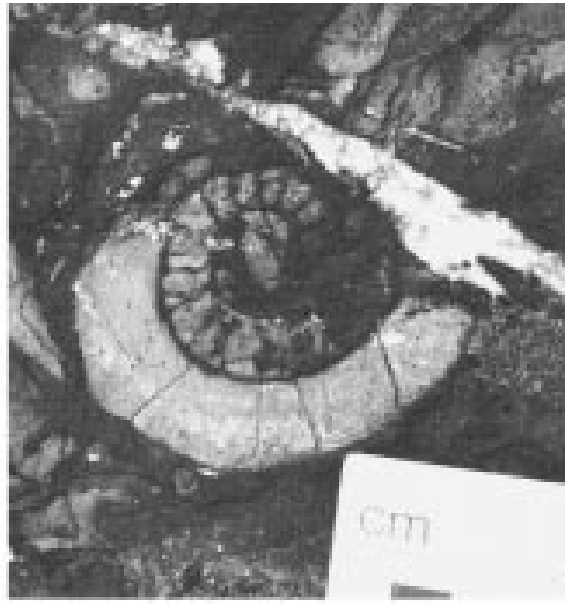

c

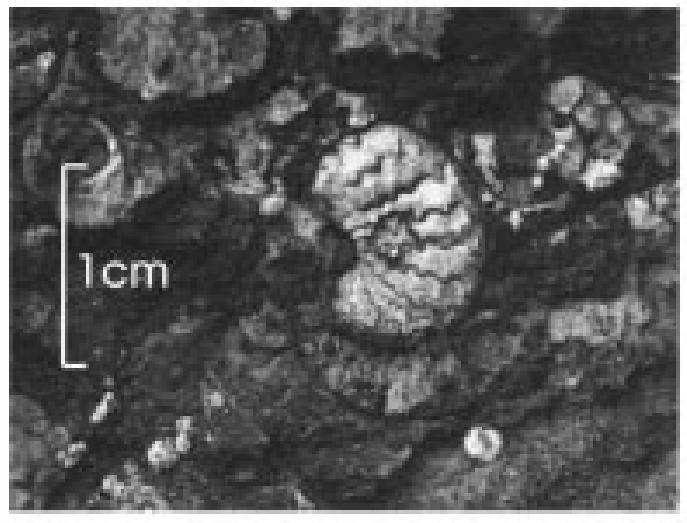

d

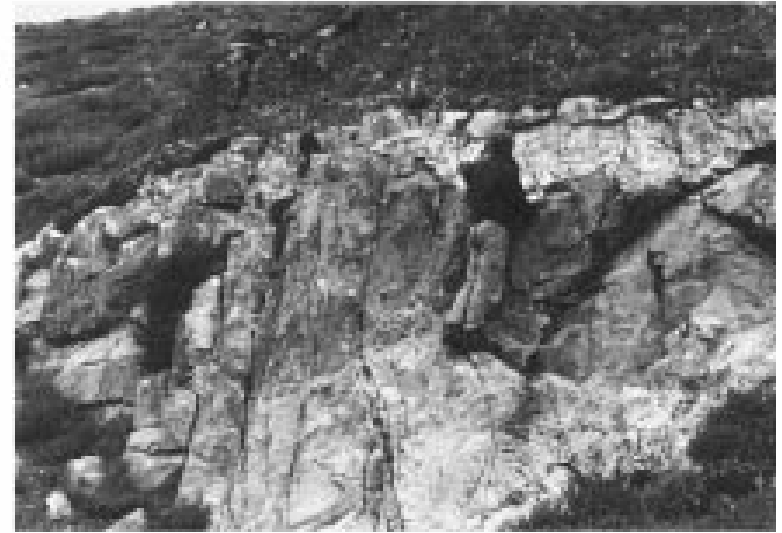

e

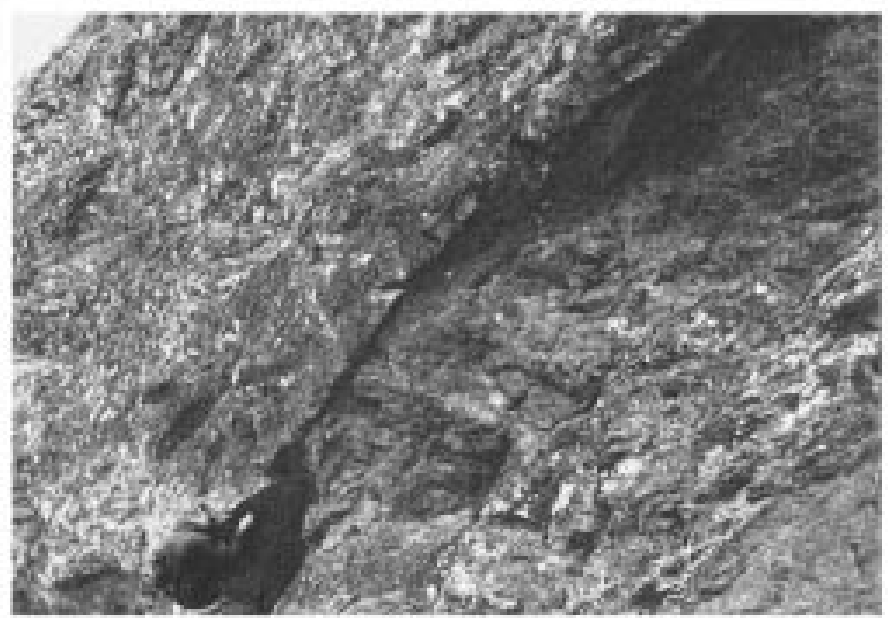

$\mathrm{f}$

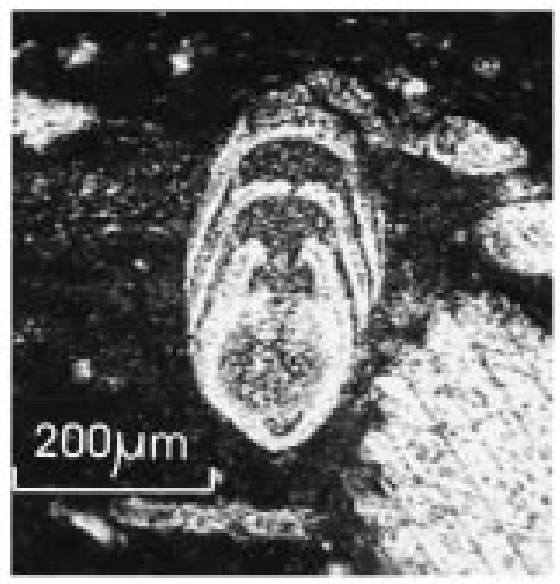

$\mathrm{h}$

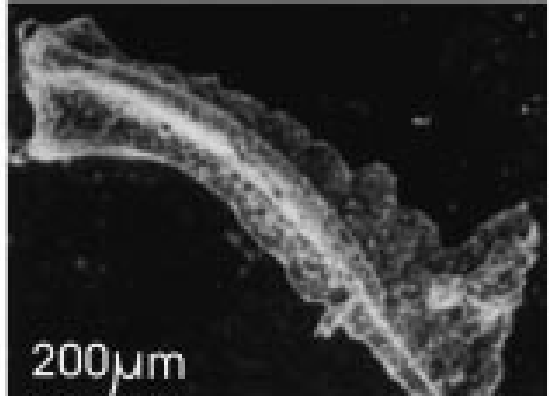


been unable to verify this age due to poor preservation of fossils in our material.

In Section A (Figs 4 \& 5) unconformably overlying the sandy limestones on an erosional contact is a volcaniclastic unit containing metric sized blocks of basaltic volcanic rocks. This unit shows very variable thickness across the exposure and is not encountered in Section B (Figs $4 \& 5$ ). The volcaniclastics are highly sheared and altered, obliterating any fossils and geochemical signatures that may have been present. Reuber et al. (1992) report a similar volcanic layer at the top of their sequence which would appear to correlate well with ours.

The top of the sequence is marked along most of its length by a calc-mylonite, containing flakes of chromite and serpentinite fragments from the over-thrusting harzburgites and the Cr-bearing muscovite variety fuchsite, weathering to a bright orange colour.

\section{Bumiktse valley section}

The Photang valley marks a major sub-vertical N-S-trending fault downthrowing to the east and is truncated by and consequently must predate the Photang thrust (Fig. 2). Upper crustal sheeted dykes and pillow lavas on the eastern side of the valley are juxtaposed against mantle harzburgites on the western side. East of this fault a thin sequence of shales, limestones, cherts and occasional volcanic rocks comprising the Photang thrust sheet in the Bumiktse valley (Fig. 2). The sequence is approximately $50-100 \mathrm{~m}$ thick and is repeated by thrusting. These thrust slices are overthrust by the volcanic rocks of the Spong arc and crustal parts of the ophiolite. Within the sequence there is very poor lateral continuity of units, which may reflect the original depositional conditions in addition to the considerable deformation that has affected these rocks. However the sequence shows many similarities to those of the Photang valley, albeit with much reduced thicknesses of volcanic rocks and greater thicknesses of sediment.

Within one outcrop approximately $15 \mathrm{~m}$ of continuous stratigraphic sequence was observed. At the base a contorted unit consisting of limestone blocks, surrounded by lavas and interbedded with grey shales is followed by a well bedded $(5-10 \mathrm{~cm}$ beds) grey limestone series. The limestone consists of very finely banded micritic material with very little, poorly preserved fossiliferous material (Fig. 6d). However Marginotruncana sp., characteristic of the ConiacianSantonian of the mid-late Cretaceous, was been identified. Over $3 \mathrm{~m}$, bands of grey shales become intercalated with the limestones in approximately equal proportions. These interbeds are overlain by $3-4 \mathrm{~m}$ of red siltstones containing occasional radiolarian chert bands, although preservation of these fossils is again very poor. Towards the top of the lower thrust slice a large and distinctive block of fossiliferous red limestone with sheared contacts is exposed. The limestone contains abundant shell and crinoid fragments and broken echinoderm plates although there is an absence of age diagnostic material in this unit.
The most striking difference in this section to those of the Photang valley are the thicker sedimentary units and the lack of the massive alkaline volcanic rocks. However the sedimentary succession and its structural character is also consistent with a seamount tectonic facies, possibly representing a flank location relative to the large volcanics thrust slices in the Photang valley to the west.

\section{Snuzi Kangri}

West of the Photang-Spong watershed (Fig. 2) the massive alkaline volcanic rocks and associated limestones south of Photoksar pinch out across the Spong valley. The termination cannot be seen as it is covered by the extensive moraine deposits characteristic of the glacial U-shaped valley. The Spong valley also coincides with a sub-vertical fault, downthrowing to the southeast. However the west side of the Spong valley in the region of Snuzi Kangri once again exposes the Spontang thrust, which places mantle harzburgites over tectonic melange, $600-800 \mathrm{~m}$ thick. No discrete thrust bound slices have been identified in this region, although blocks of alkaline volcanics associated with limestones are present. The melange contains blocks of limestones, serpentinized peridotites, cherts, dark pyritic shales, basaltic volcanic rocks and composite blocks, ranging from metres to hundreds of metres in size, within a serpentinitic matrix. These tectonic melanges are a structurally continuous part of the Photang thrust sheet.

The base of the thrust sheet is also marked by a very distinct green weathered band of serpentinite across the Snuzi Kangri area reaching thicknesses of over $20 \mathrm{~m}$. Ophicalcites are commonly associated with these serpentinites and in one locality a ferruginous crust was observed on the top surface overlain by dark serpentinitic shales. These serpentinites are considered to be derived from oceanic crust underlying the tectonic melanges of the Photang thrust sheet. A possible occurrence of Lower Eocene radiolarian cherts have been reported from the Spong valley region, although there is a lack of consensus on the exact field relations, Colchen \& Reuber (1986), Colchen et al. (1987) and Reuber et al. $(1987,1992)$ offering different accounts of the same data. This potentially important age was based on the identification of the radiolaria Lamptonia pennata and Lamptonia fabaeforma; however no evidence has been presented from which this can be verified.

\section{Middle-Upper Photang valley}

Kilometre sized blocks of volcanic rocks are characteristic of the Photang valley (Fig. 2). Geochemical analysis of samples from these larger blocks indicate mid-ocean ridge and islandarc affinities (see Fig. 9). Other smaller blocks of volcanics commonly consist of highly vesicular pillow lavas of alkaline chemistry, consistent with formation in an intra-plate setting (see Fig. 9). Limestones are common as individual blocks as well as associated with igneous rocks and range in age from Permian to late Cretaceous (Colchen et al. 1987). No limestone

Fig. 6. Illustrations from the log sections (Fig. 4) through the Photang thrust sheet. (a) Well formed pillow lavas, $210 \mathrm{~m}$, section A (b) Ammonite encased in basaltic lava, $155 \mathrm{~m}$, section B. (c) Goniatite, $150 \mathrm{~m}$ section B. (d) White, unfossiliferous, massive bedded limestone, 5-10 m, Section B. (e) Imbricate thrust fault, 25 m, Section B. (f) Fusulinid foraminifer, longitudinal section of juvenarium (Colaniella sp. OUMNH FY.415), 70 m, section B. (g) Globotruncana calcarata, axial section OUMNH KY.2191, from continental slope deposits at the base of section B. (h) Lateral SEM view of Metapolygnathus spp. OUMNH GY.233 (conodont), 92 m, Section B. 
blocks younger than late Cretaceous have been found anywhere within the Photang thrust sheet.

\section{Photok Unit}

Well-stratified black and red slates passing upwards into sedimentary melanges and olistostromes crop out all around the southern and western edges of the Spontang ophiolite. At the Photok La (Fig. 1) the base of the sequence has previously been named the Photok La Slates and contains Hedbergella sp. and Globotruncana sp. indicating a Campanian age (Reuber et al. 1992). We interpret these deep water pelagic sediments and calci-turbidites to have deposited in a base of continental slope setting. Reuber et al. (1992) illustrated several sketch sections from the Photok La region onto which palaeontological data from Colchen et al. (1987) was annotated. The majority of age determinations indicated a late Cretaceous age for the matrix of the rocks with the exception of two lower Eocene ages (Colchen et al. 1987). The foraminifera Nummulites globulus and Miscellanea globularis were identified from a limestone lense within the matrix, and Assilina spinosa and Assilina dandotica were identified from the matrix itself. Re-mapping of this region showed that Late Cretaceous sedimentary melanges of the Photok unit are thrust over Eocene north Indian continental margin deposits in this region (Searle et al. 1997; Corfield \& Searle in press) previously interpreted to be from a continuous sedimentary section through melanges (Colchen et al. 1987; Reuber et al. 1992). We found no evidence of sedimentary melanges younger than Late Cretaceous in age.

\section{Lamayuru Complex}

Beneath the Photang thrust sheet and the Photok unit is a further distinct allochthonous thrust sheet of Mesozoic north Indian continental-margin slope deposits which overlies the Mesozoic passive margin sequence. The Lamayuru Complex in the Indus Suture zone has been described in some detail by Robertson \& Degnan (1993) and comprises remnants of the Triassic to Late Cretaceous, north facing north Indian continental margin, preserving slope to base of slope facies associations. The Triassic-Jurassic sequence consists of quartzose turbidites, calc-turbidites, shales and limestone 'exotics' related to extensional collapse of the carbonate platform edge in the mid-Jurassic. A period of extension-related alkaline volcanism in the late Jurassic is also recorded in the west of the area (Robertson \& Degnan 1993). Mixed quartzose clastic, volcaniclastic, radiolarian-bearing carbonates characterize the poorly dated Cretaceous portion of the formation.

The youngest Lamayuru complex rocks underneath the Photang thrust sheet are argillaceous largely dark grey to black, beige weathering slates. The rocks are locally calcareous and rustier weathering impure sandstones are commonly found interbedded with the slates and form competent units (e.g. along the ridge south of Sirsir La, Fig. 2). The rocks have been variously interpreted as belonging to the upper parts of the Lamayuru Complex (Bassoullet et al. 1978; Searle et al. 1988), the Campanian-Maastrichtian passive margin (Kangi La Formation, Keleman \& Sonnenfeld 1983) and as the Campanian-Maastrichtian outer passive margin (Goma Formation or Dumbur Formation, Cannat \& Mascle 1990). We favour a distal slope setting for these sediments, being generally finer grained and more calcareous than the silty arenaceous Kangi La formation. Discovery of an Oxfordian/ Callovian (Jurassic) ammonite from this formation immediately south of the Photoksar break-back thrust, to the west of the Spong river (Brookfield \& Westermann 1982) is only consistent with interpretation of the slates as substantially allochthonous Mesozoic slope deposits of the Lamayuru Complex.

Sparse exposures around the village of Yulchung (Fig. 7) consist of blocks and layers of fine-grained sandstones and micritic pelagic limestones within the dominant dark shaly facies. The unit as a whole is highly deformed and is thrust over the passive margin shelf deposits. The thrust contact can be clearly seen in the cliffs all along the north side of the Stumpata valley (Fig. 8), and round into the cliffs of the Zanskar gorge opposite Nerak (see Searle et al. 1997, Fig. 6). This allochthonous unit consists of the upper portions of the Lamayuru continental slope deposits and truncates structures in the mid Cretaceous Fatu La pelagic limestones. The thrust sheet is itself truncated by deposition of the latest Cretaceous to early Eocene Spanboth formation (Fig. 7), clearly dating the deformation phase as late Cretaceous or older. This deformation event was associated with obduction of the Spontang ophiolite. West of Fig. 7, in the Marling valley the thrust contact placing the Spontang ophiolite over the early Tertiary limestones can be constrained to within $10 \mathrm{~m}$. This thrust cuts across the Tertiary limestones and is extrapolated onto the line of section in Fig. 7. Restoration of this thrust requires that the limestones in the hanging wall must have originally overlain the ophiolite but have since been removed by erosion.

\section{Geochemistry}

Whole rock analyses of six samples from limestone capped volcanic sequences of the Photang thrust sheet and 13 samples from melange blocks within the Photang thrust sheet have been carried out using X-ray fluorescence. All the rocks exhibit significant alteration, consequently we have restricted any chemical discrimination to those incompatible elements relatively unaffected by alteration processes, following the method of Pearce (1996). All samples were screened using a Ti/Zr-Ni diagram (Winchester et al. 1980) to ensure no metasediments were included. Element mobility was tested by plotting groups of samples from related suites against their loss of ignition values as an index of alteration. A $\mathrm{Zr} / \mathrm{Ti}-\mathrm{Nb} / \mathrm{Y}$ discrimination diagram (Winchester \& Floyd 1977; Pearce 1996; Fig. 9a) was used to separate the more evolved igneous rocks. Following this screening procedure the basaltic samples were plotted on various discrimination diagrams (Meschede 1986; Pearce \& Cann 1971, 1973; Wood et al. 1979; Shervais 1982; Fig. 9). To use the ternary 3Hf-Th-Ta plot (Fig. 9e) we have assumed $\mathrm{Zr} / \mathrm{Hf}$ and $\mathrm{Nb} / \mathrm{Ta}$ ratios of 39 and 16 respectively (Wood et al. 1979; Pearce 1996) since Hf and Ta concentrations are not measured by XRF. When used in isolation these diagrams have been shown by several authors to produce erroneous results, particularly for continental tholeiites and Archean rocks (e.g. Holm 1982). However when used in combination the diagrams yield important constraints on tectonic setting (Pearce 1996).

The chemistry of the limestone capped volcanic rocks of the Photang thrust sheet is alkaline (Fig. 9). Three samples are classified as phonolites (Fig. 9a) and have not been plotted on the basalt discrimination diagrams. The other three sample are classified as alkali basalts and consistently plot in, or very near the within plate alkaline field (Fig. 9b-f). 


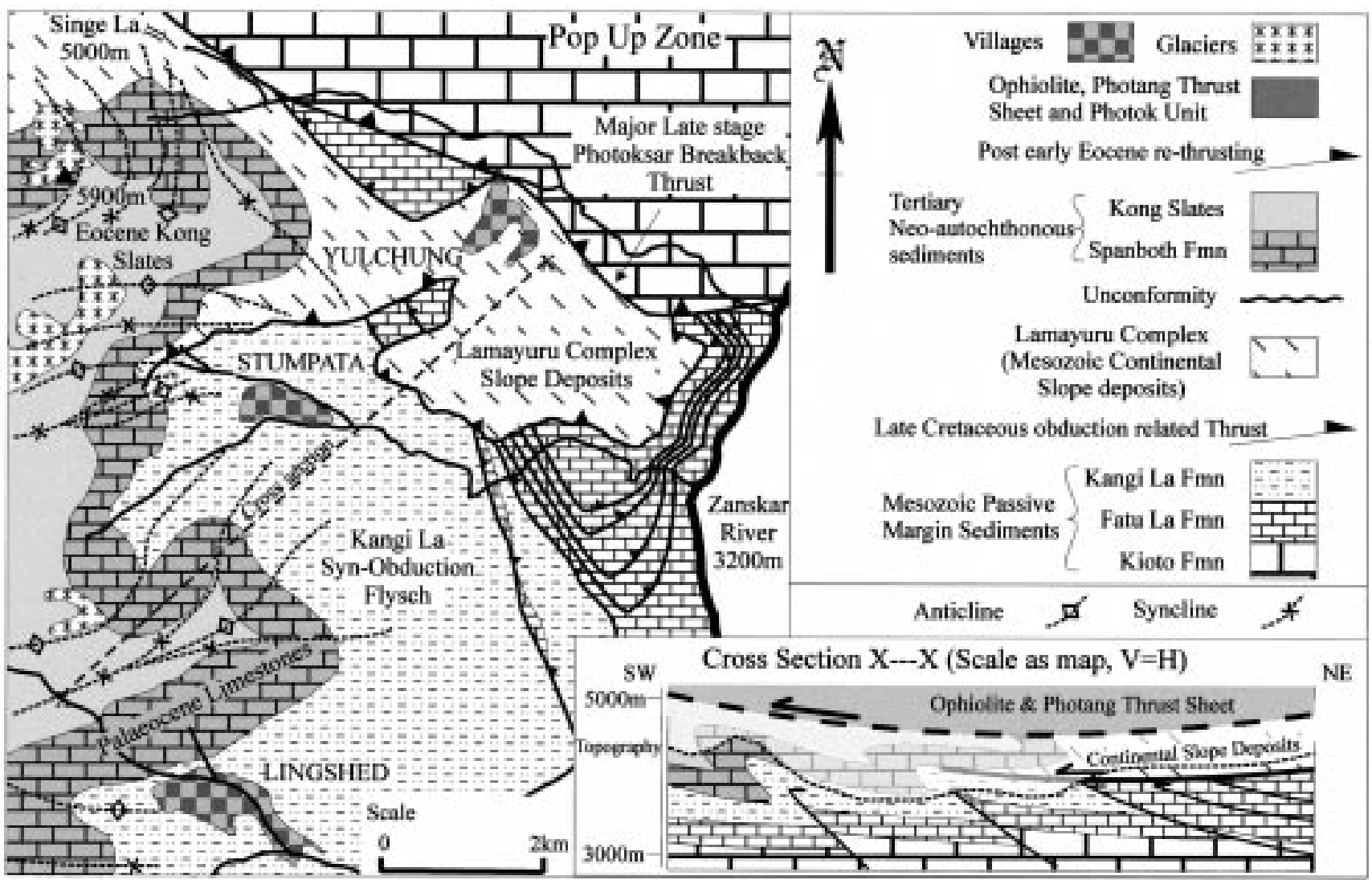

Fig. 7. Geological map and cross-section of the Yulchung-Lingshed region (located on Fig. 1). The Zanskar river gorges passes immediately east of the Spontang ophiolite exposing a $2500 \mathrm{~m}$ section through the rocks immediately beneath the Spontang ophiolite. A major thrust places Mesozoic distal continental slope deposits onto the intensely deformed Mesozoic sediments of the Indian passive margin in this region (Fig. 8). This thrust is truncated by the deposition of latest Cretaceous to early Eocene shallow marine limestones in the cliffs west of Stumpata village. Therefore movement on the thrust, which must have predated deposition of the limestones, was late Cretaceous or older. The position of the ophiolite and Photang thrust sheet is extrapolated onto the line of cross-section from structures immediately west of the map area.

The second set of rocks was sampled from blocks within the tectonic melanges of the Photang thrust sheet. Several of the samples are andesitic in composition (Fig. 9a) and have not been plotted on the basalt discrimination diagrams. However, the common occurrence of andesitic volcanic rocks in association with carbonate sediments and volcaniclastic rocks strongly suggests an arc setting for the origin of these rocks.

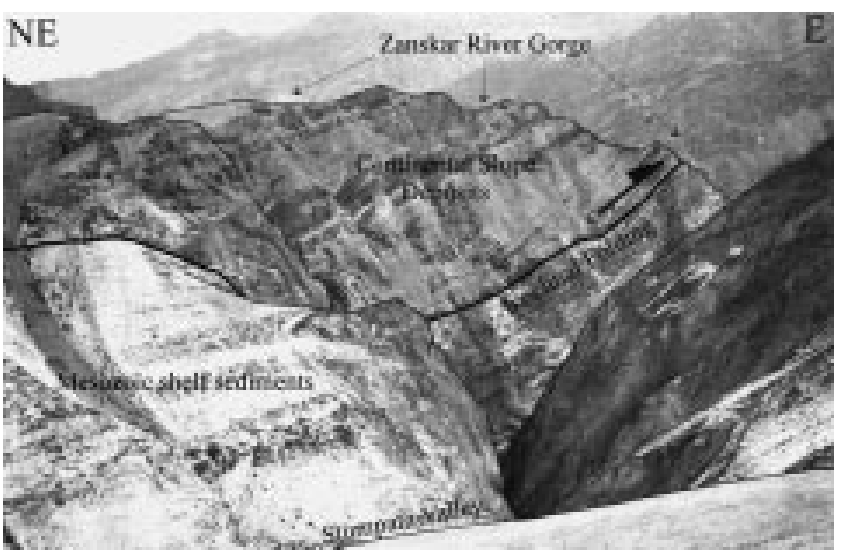

Fig. 8. View of the cliffs on the north side of the valley, downstream from Stumpata village (Fig. 7). Thrusting of the continental slope deposits onto the shelf sediments is associated with intense deformation including isoclinal folding in the hanging wall.
This group of samples as a whole shows considerable scatter on all the diagrams. probably reflecting the fact that blocks of varied affinities would have been incorporated into the melange, including ophiolitic and arc related rocks from the obducted thrust sheets and alkaline volcanic rocks from accreted seamounts. The samples have been divided into two clear groupings of within plate alkaline lavas and tholeiitic mid-ocean ridge or island arc basalts on all the discrimination diagrams (Fig. 9)

\section{Discussion}

In common with other similar sub-ophiolite thrust sheets such as the Haybi complex beneath the Oman ophiolite (Searle et al. 1980), the Mamonia complex associated with the Troodos ophiolite in Cyprus (Robertson \& Woodcock 1979) and the Coastal complex beneath the Bay of Islands ophiolite in Newfoundland (Casey et al. 1983), it is the rocks underlying the ophiolite which give an indication of its tectonic setting and obduction history.

In the detailed sections studied through the Photang thrust sheet two distinct thrust slices of volcanic rocks and associated marine sediments, separated by tectonic melanges have been identified. The highest thrust slice of the sequence described, though showing considerable variability along strike, shows a similar sequence to the section described by Reuber et al. 

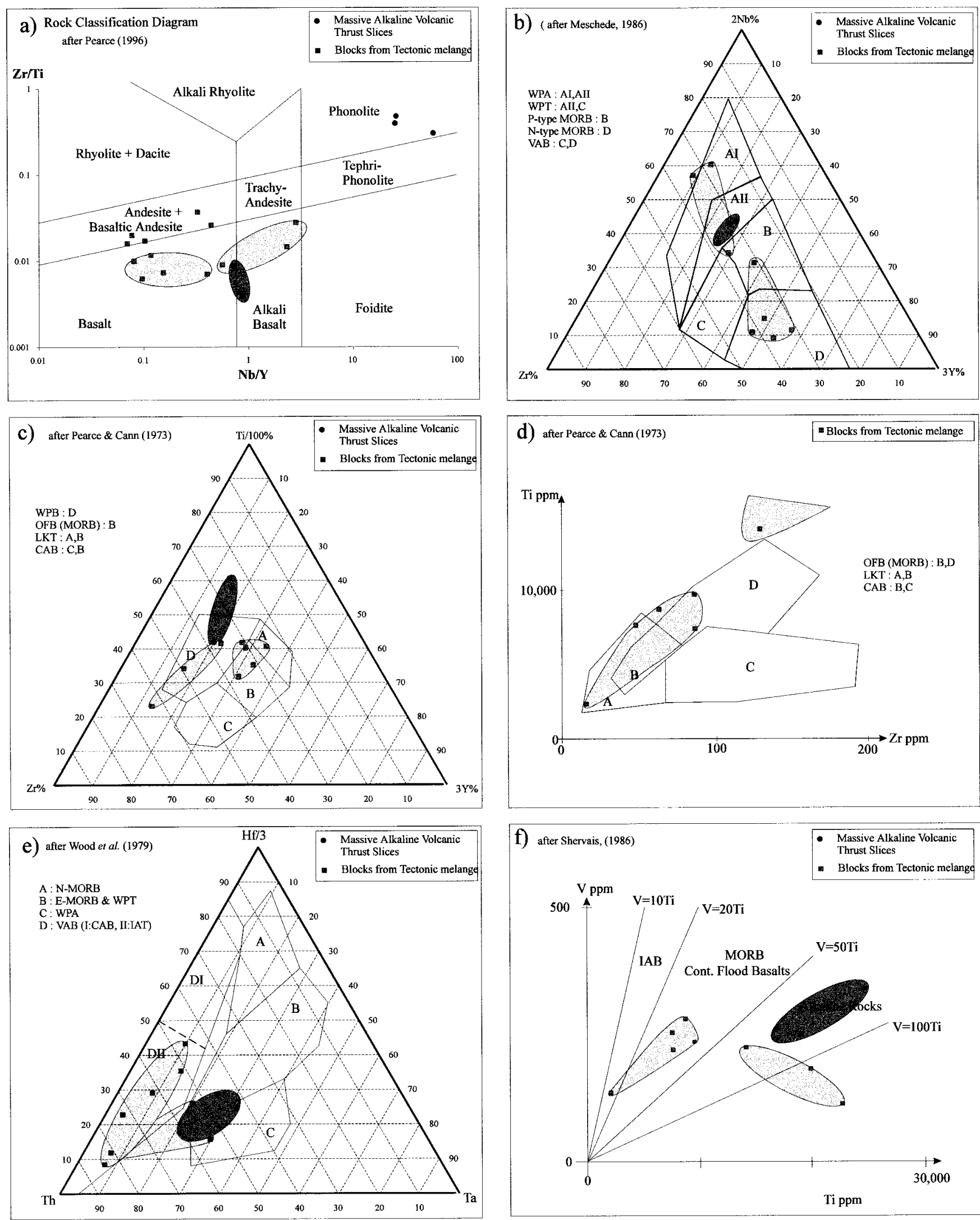

Fig. 9. Tectonic discrimination diagrams showing trace element geochemistry of basaltic samples from the Photang thrust sheet. (a) $\mathrm{Zr} / \mathrm{Ti}-\mathrm{Nb} / \mathrm{Y}$ rock classification diagram after Pearce (1996). (b) $2 \mathrm{Nb}-\mathrm{Zr}-3 \mathrm{Y}$ after Meschede (1986), WPA, within plate alkaline; WPT, within plate tholeiite; N-type MORB, oceanic basalt from a normal mid-ocean ridge; P-type MORB, basalt from plume influenced MOR; VAB, volcanic arc basalt. (c) Ti/100-Zr-3Y after Pearce \& Cann $(1971,1973)$, WPB, within plate basalt; OFB, ocean floor basalt; LKT, low potassium tholeiite; CAB, calc-alkaline basalt. (d) Ti-Zr after Pearce \& Cann (1971, 1973). (e) Hf/3-Th-Ta after Wood et al. (1979) E-MORB, oceanic basalt from an anomalous MOR segment (e.g. high heat flow). (f) V-Ti after Shervais (1982); IAB, Island-arc Basalt; MORB, Mid-ocean ridge basalt. 
(1992). These thrust slices are interpreted to have arisen from thrusting over a considerable period of time, such as might be found in a subduction zone environment. Northwards subduction of Indian plate oceanic crust would have been expected to consume progressively older crust overlain by progressively younger pelagic sediments. This sequence is preserved in the thrust slices of the accretionary complex. The lowest thrust slice (the last to accrete) consists of alkaline volcanic rocks with Permian limestone lenses, capped by Upper Cretaceous pelagic carbonates with an erosional contact. The highest thrust slice of the sequence preserves a more complete stratigraphy from the late Permian into the midCretaceous (Albian), the youngest sediments of which are older than the youngest sediments in the lower thrust slice. The temperature estimate of $>300^{\circ} \mathrm{C}$ based on conodont colour is consistent with an accretionary environment of formation for the melange with subsequent over-thrusting by the ophiolitic rocks in the hanging wall of the subduction zone.

The geochemistry of these volcanic rocks is clearly consistent with the field interpretations that they originated as intra-oceanic seamounts, onto which Permian to Cretaceous carbonate sediments were deposited. An analogous facies association has been described from the Indus Suture Zone by Robertson (1998) interpreted as having formed as a shallow water carbonate platform in the Permian open to the NeoTethyan ocean to the north which subsequently subsided and detached from the southern Tethyan margin to form a volcanic seamount. The section through the Photang thrust sheet in the Bumiktse valley is also consistent with this interpretation preserving seamount flank facies associations laterally connected to the thicker seamount thrust slices in the Photang valley to the west.

A metamorphic sole is definitely absent along most and possibly all of the basal contact of the ophiolite with the Photang thrust sheet. The lack of a metamorphic sole could reflect cold conditions at the time of obduction or could be an artefact of poor preservation due to re-thrusting and erosion. However the high $\mathrm{K}$ amphibolite, associated with meta-chert described and dated by Reuber et al. (1989) is evidence that a metamorphic sole may have existed. The Spontang ophiolite is highly fragmented on a large scale, almost certainly due to its origin from the leading edge of a subduction zone hanging wall. This complexity extends to the structural relationship of the ophiolite to the Photang thrust sheet, therefore the lack of a clearly defined metamorphic sole is not surprising.

The Photok unit is a distinct thrust-bound unit exposed beneath the Photang thrust sheet and is considered to represent late Cretaceous base of slope deposits grading upwards into sedimentary melanges associated with ophiolite obduction. These calci-turbidites, pelagic carbonates and shales may correlate with the upper Cretaceous parts of the Karamba Complex exposed in the Indus Suture zone (Robertson \& Sharp 1998). These authors have pointed out that the end of proven deposition on the continental slope and base of slope in the late Cretaceous favours the model of late Cretaceous ophiolite obduction.

The lowest allochthonous thrust sheet consists of Mesozoic Lamayuru complex, north Indian continental-margin slope deposits. Structural relationships in the Yulchung region (Figs $7 \& 8$ ) indicate that this allochthonous thrust sheet was emplaced in the late Cretaceous and subsequently overlain by shallow marine, Maastrichtian to Early Eocene limestones. The Spontang ophiolite, Photang thrust sheet and Photok unit were also obducted onto the north Indian continental margin at this time. However re-thrusting following India-Asia collision in the early Eocene has placed them on top of the early Tertiary neo-autochthonous cover (Corfield \& Searle in press).

\section{Tectonic evolution}

We now consider the constraints which can be placed on the tectonic evolution of the Spontang ophiolite which are summarized in a model of the tectonic evolution (Fig. 10).

The Photang thrust sheet has been described in detail as an accretionary complex incorporating sediments ranging from Permian to late Cretaceous in age. Consequently this accretionary complex must have formed above a subduction zone active at least into the late Cretaceous. Spong Arc volcanic rocks formed on the basement of the Spontang ophiolite dated as $91 \pm 3 \mathrm{Ma}$ (Pedersen et al. in review) probably formed above this subduction zone providing a minimum age of subduction initiation. There is no evidence for any sediments younger than late Cretaceous within the Photang thrust sheet, or in the allochthonous continental slope deposits immediately beneath it. Qualitative restoration of the allochthonous thrust sheets, assuming a foreland propagating sequence of thrusting gives rise to a tectonic reconstruction of the subduction zone in the late Cretaceous (Fig. 10a). The Spontang ophiolite restores to the hanging wall of the subduction zone at which the Photang thrust sheet was forming. A subduction zone immediately north of the Indian passive margin in the late Cretaceous has been suggested by several authors (Burg 1983; Burg \& Chen 1984; Moores et al. 1980; Besse \& Courtillot 1988; Beck et al. 1996; Gnos et al. 1997). Our interpretation provides further evidence that this subduction zone may have been a continuous feature north of the Indian continent during the late Cretaceous from southern Tibet to western Pakistan.

The allochthonous thrust sheet of continental slope deposits, truncated by deposition of latest Cretaceous to early Eocene limestones in the Yulchung region, clearly indicates that obduction had taken place by the late Cretaceous (Fig. 10b). Palaeomagnetic plate reconstructions indicate that the northern margin of India was greater than $1000 \mathrm{~km}$ south of the southern Asian margin at this time (Dewey et al. 1989). By this time the Dras-Kohistan island-arc had also accreted to the Asian plate (Schärer et al. 1984; Coward et al. 1987; Robertson \& Degnan 1994). Clearly there can be no association between the Spontang ophiolite and the Dras volcanic arc, as has been suggested by several authors (Reibel \& Reuber 1982; Searle et al. 1988).

Northwards motion of India towards Asia continued during the early Tertiary, collision in the Ladakh region dated by final marine sedimentation in the Indus Suture Zone at $54 \mathrm{Ma}$ (Garzanti \& Van Haver 1988). This is also consistent with palaeomagnetic data which indicates a slowing in the northwards motion of India relative to Asia from $18-19.5 \mathrm{~cm} / \mathrm{a}^{-1}$ to $4.5 \mathrm{~cm} / \mathrm{a}^{-1}$ at $c .55 \mathrm{Ma}$ (Klootwijk et al. 1992). Magmatism in the Ladakh batholith was also active into the early Tertiary due to continued subduction beneath the southern Asian margin (Schärer et al. 1984). Ophiolite melange zones formed at the northern and southern margins of the Dras arc are preserved in the Indus Suture Zone.

Following collision, compression of the northern Indian continental margin resulted in reactivation of thrusting beneath the Spontang ophiolite, Photang thrust sheet and 
a) $80 \mathrm{Ma}$ - Immediately prior to obduction

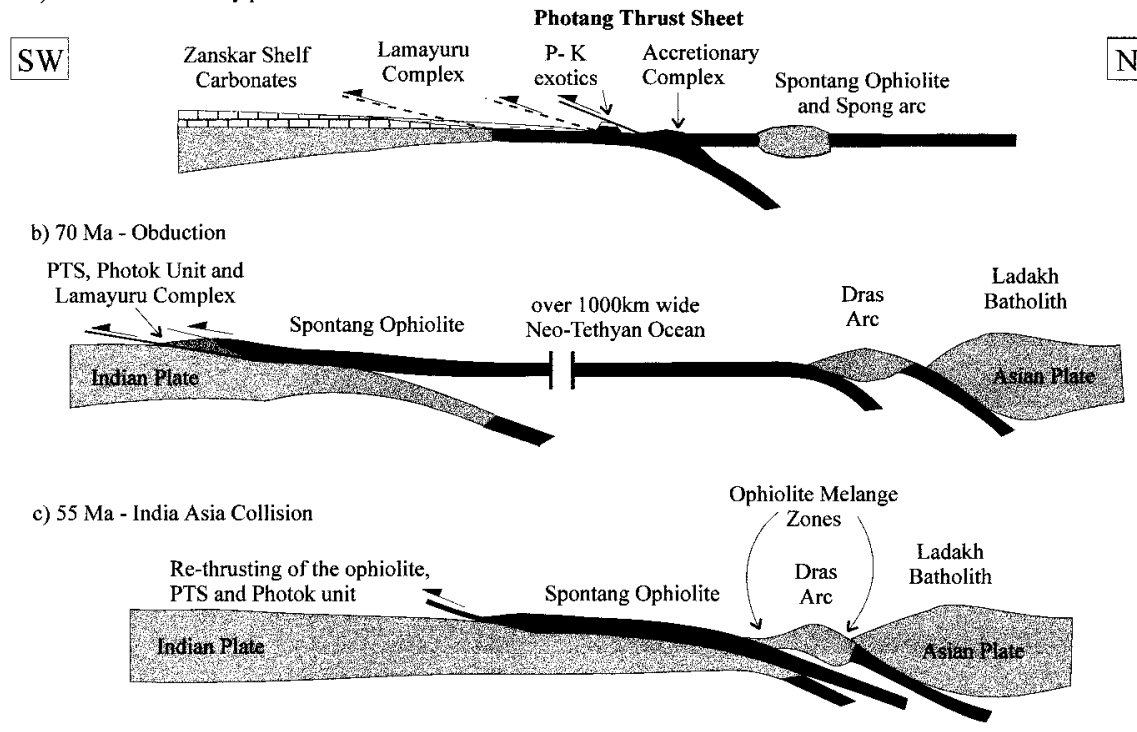

d) $30 \mathrm{Ma}$ - Post Collision
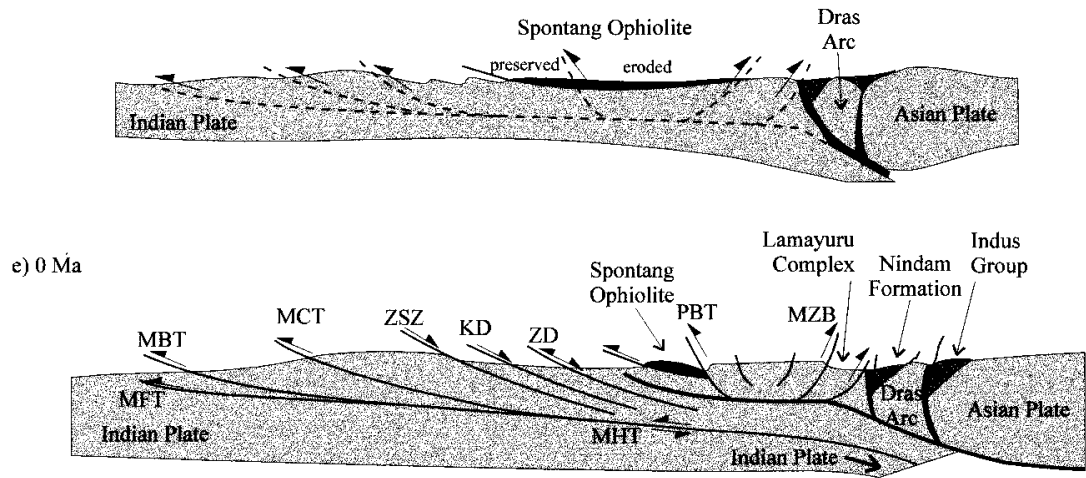

Approximate Scale

$\begin{array}{lll}0 \quad 10 & 50 \mathrm{~km}\end{array}$

Photok unit (Searle 1986; Corfield \& Searle in press). This re-thrusting cuts across the early Tertiary limestones which were deposited over the allochthonous thrust sheets, placing the hanging-wall units structurally above these limestones (Searle et al. 1997, fig. 11). The lowest allochthon of continental slope deposits escaped re-thrusting.

Continuing convergence between India and Asia caused late Tertiary refolding and thrusting of the entire sequence (Fig. 10d-e). The Photoksar break-back thrust placed lower level Mesozoic shelf carbonates in the hanging wall over the obducted thrust sheets in the footwall and was probably active concomitantly with the NE-directed Main Zanskar backthrust along the southern margin of the Indus Suture Zone (Searle et al. 1988, 1997). The Photoksar thrust remains topographically significant and is responsible for the preservation of the Spontang ophiolite, the rest of the obducted slab having been removed by erosion.

\section{Conclusions}

The Spontang ophiolite is one of the few important remnants of oceanic crust obducted onto the Mesozoic passive margin of the northern Indian plate still preserved in the Himalaya. Detailed mapping with structural, sedimentological, palaeon-
Fig. 10. Model for the structural evolution of the Photang thrust sheet in the Ladakh Himalaya. PTS, Photang thrust sheet; MFT, Main Frontal Thrust; MBT, Main Boundary Thrust; MCT, Main Central Thrust; MHT, Main Himalayan Thrust; ZSZ, Zanskar Shear Zone; KD, Karsha Detachment; ZD, Zangla Detachment; PBT, Photoksar break-back thrust; MZB, Main Zanskar backthrust. tological and geochemical analysis show that a distinct thrust sheet (the Photang thrust sheet) structurally underlies the ophiolite. The thrust sheet comprises distinct thrust slices of alkaline volcanic rocks overlain by pelagic carbonates, ranging from Permian to late Cretaceous in age. Tectonic melanges within the thrust sheet contain blocks of volcanic rocks, serpentinized harzburgites, deep-sea sediments and limestones, also of Permian to Cretaceous age. Trace element geochemistry of the alkaline basalts suggest that they were erupted in a within plate setting, possibly as off-axis oceanic islands. The Photang thrust sheet is interpreted as a subduction accretionary complex that formed through thrusting over a considerable period of time up to the late Cretaceous.

Structures of the Yulchung region indicate that ophiolite obduction must have taken place by the late Cretaceous, which is consistent with the age of the youngest sediments in each of the allochthonous thrust sheets underlying the Spontang ophiolite. The Photang thrust sheet immediately underlies the Spontang ophiolite and restores to a position immediately south of the ophiolite prior to obduction. It follows that the Spontang ophiolite and associated Spong arc must have existed in the hanging wall of the subduction zone at which the accretionary complex formed in the late Cretaceous. This subduction zone was responsible for initial detachment of 
oceanic lithosphere and evolved into a southwest directed shallow level thrust system with time, emplacing the ophiolite and Photang thrust sheet onto the north Indian passive margin continental margin. Associated with ophiolite obduction distinct thrust slices of sedimentary melanges (Photok unit) and continental slope deposits (Lamayuru Complex) were also emplaced onto the north Indian continental margin beneath the Spontang ophiolite and Photang thrust sheet. Postcollisional thrusting and folding of the obducted thrust sheets has resulted in the preservation of the Spontang ophiolite in the hanging wall of a late-stage southwest directed break-back thrust.

This work was funded by grants from NERC (UK), studentship GT4/95/247/E to R.I.C., grant GT5/96/13E to M.R.S. and also the Oxford University, Department of Earth Sciences Burdett Coutts trust fund. Thanks also to R. Pedersen and R. Bisley for many enlightening discussions in the field, I. Sansom and M. Orchard for their micro-vertebrate identifications and also to Lobsang \& Namgal Tsering of Leh, Fida Hussein of Leh and Lobsang Namgal of Pishu. This manuscript has benefited from constructive reviews by $\mathrm{R}$. Weinberg, E. Gnos and an anonymous referee.

\section{References}

Alleman, F. 1979. Time of emplacement of the Zhob valley ophiolites and Bela ophiolites, Baluchistan (preliminary report). In: FARAH, A. \& DEJong K.A. (eds) Geodynamics of Pakistan. 215-242.

Bassoullet, J.-P., Colchen, M., Juteau, T., Marcoux, J. \& Mascle, G. $1980 a$. L'edifice de nappes du Zanskar (Ladakh, Himalaya). Comptes Rendus de l'Academie des Sciences, Paris, 290, Serie D, 389-392.

,-- Marcoux, J. \& Mascle, G. 1978. Une transversale de la zone de l'Indus de Khalsi a Photoksar, Himalaya du Ladakh. Comptes Rendus de l'Academie des Sciences, Paris, 286, Serie D, 563-566.

$-1-19-1980 \mathrm{~b}$. Field evidences for continental rifting in Triassic time in the Ladakh part of the Indus Suture Zone. In: Proceedings of Symposium on Quinghai-Xizang (Tibet), Beijing, 1981.

Baud, A., Gaetani, M., Garzanti, E., Fois, E., Nicora, A. \& Tintori, A. 1984. Geological observations in south-eastern Zanskar and adjacent Lahul area (north-western Himalaya). Eclogae Geologicae Helvetiae, 77, 171-197.

Beck, R.A., Burbank, D.W., Sercombe, W.J., Khan, A.M. \& Lawrence, R.D. 1996. Late Cretaceous ophiolite obduction and Paleocene India-Asia collision in the westernmost Himalaya. Geodynamica Acta (Paris), 9/2, 114-144.

,$--\frac{-}{-}$, Riley, G.W., Barndt, J.K., Berry, J.R., Afzal, J., Khan, A., Jurgen, H., Metje, J., Cheema, A., Shafique, N.A., Lawrence, R.D. \& KHAN, M.A. 1995. Stratigraphic evidence for an early collision between Northwest India and Asia. Nature, 373, 55-58.

Besse, J. \& Courtillot, V. 1988. Paleogeographic maps of the continents bordering the Indian Ocean since the Early Jurassic. Journal of Geophysical Research, 93, B10, 11 791-11808.

Brookfield, M.E. \& ANDREws-SpeEd, C.P. 1984. Sedimentology, petrography and tectonic significance of the shelf, flysch and molasse clastic deposits across the Indus Suture Zone, Ladakh, NW India. Sedimentary Geology, 40, 249-286.

\& Westermann, G.E.G. 1982. Mesozoic ammonites from the Spong valley, Zanskar, NW India. Journal of the Geological Society of India, 23, 263-266.

BurG, J.-P. 1983. Tectogenese comparee de deux segments de chaine de collision: Le sud du Tibet (Suture du Tsangpo), La chaine hercynienne en Europe (Sutures du Massif Central). These Universite des sciences et Techniques du Languedoc.

\& Chen, G. M. 1984. Tectonics and structural zonation of southern Tibet, China. Nature, 311, 219-223.

Cannat, M. \& Mascle, G. 1990. Reunion extraordinaire de la societe geologique de France en Himalaya du Ladakh. Bulletin de la Societe Geologique de France, 8, VI, 553-582.

Casey, J.F., Karson, J.A., Elthon, D., Rosencrantz, E. \& Titus, M. 1983. Reconstruction of the geometry of accretion during formation of the Bay of Islands ophiolite complex. Tectonics, 2, 509-528.

Colchen, M. \& Reuber, I. 1986. Les mélanges ophilitiques du Zanskar, Himalaya du Ladakh. Comptes Rendus de l'Academie des Sciences, Paris, 303, 719-724
- Mascle, G. \& van Haver, T. 1986. Some aspects of collision tectonics in the Indus suture zone, Ladakh. In: Coward, M.P. \& Ries, A.C. (eds) Collision Tectonics. Geological Society, London, Special Publications, 19, 173-184.

— Reuber, I., Bassoullet, J-P., Bellier, J-P., Blondeau, A., Lys, M. \& De WeVer, P. 1987. Donnes biostratigraphiques sur les melanges ophiolitiques du Zanskar, Himalaya du Ladakh. Comptes Rendus de l'Academie des Sciences, Paris, Serie II, 305, 403-406.

Corfield, R.I. \& Searle, M.P. in press. Crustal Shortening estimates across the north Indian continental margin, Ladakh, NW India.

Coward, M.P., Butler, R.W.H., Khan, M.A. \& KniPe, R.J. 1987. The tectonic history of Kohistan and its implications for Himalayan structure (Pakistan). Journal of the Geological Society (London), 144, 377-391.

Dewey, J.F., Cande, S. \& Pitman, W.C. 1989. Tectonic evolution of the India/Eurasia collision zone. Eclogae Geologicae Helvetiae, 82, 717-734.

Epstein, A.G., Epstein, J.B. \& Harris, L.D. 1977. Conodont colour alteration - an index to organic metamorphism. United States Geological Survey, Professional Paper, 995, 1-27.

Fuchs, G. 1977. Traverse of Zanskar from the Indus to the Valley of Kashmir - a preliminary note. Jahrbuch der Geologischen Bundesanstalt, 120/2, 165-217.

— 1979. On the Geology of Western Ladakh. Jahrbuch der Geologischen Bundesanstalt, 122/2, 513-540.

— 1982. The Geology of Western Zanskar. Jahrbuch der Geologischen Bundesanstalt, 125, 1-50.

— \& Willems, H. 1990. The final stages of sedimentation in the Tethyan zone of Zanskar and their geodynamic significance (Ladakh-Himalaya). Jahrbuch der Geologischen Bundesanstalt Wien, 133, 259-273.

Gansser, A. 1964. Geology of the Himalayas. J. Wiley, London.

Gaetani, M. \& Garzanti, E. 1991. Multicyclic history of the Northern India Continental Margin (Northwestern Himalaya). American Association of Petroleum Geologists Bulletin, 75, 1427-1446.

Garzanti, E. \& VAn Haver, T. 1988. The Indus Clastics: forearc basin sedimentation in the Ladakh Himalaya (India). Sedimentary Geology, 59, 237-249.

— BAud, A. \& Mascle, G. 1987. Sedimentary record of the northward flight of India and its collision with Eurasia (Ladakh Himalaya, India). Geodynamica Acta (Paris), 1, 297-312.

Gnos, E., Immenhauser, A. \& Peters, Tu. 1997. Late Cretaceous/early Tertiary convergence between the Indian and Arabian plates recorded in the ophiolites and related sediments. Tectonophysics, 271, 1-19.

HoLm, P.E. 1982. Non-recognition of continental tholeiites using the Ti-Y-Zr diagram. Contributions to Mineralogy and Petrology, 79, 308-310.

Honegger, K., Dietrich, V., Frank, W., Gannser, A., Thoni, M. \& TrommsdorfF, V. 1982. Magmatism and metamorphism in the Ladakh Himalayas (the Indus-Tsangpo suture zone). Earth and Planetary Science Letters, 60, 253-292.

Keleman, P.B. \& Sonnenfeld, M.D. 1983. Stratigraphy, structure, petrology and local tectonics, Central Ladakh, NW Himalaya. Schweizerische Mineralogische und Petrographische Mitteilungen, 63, 267-287.

—, Reuber, I. \& Fuchs, G. 1988. Structual evolution and sequence of thrusting in the High Himalayan, Tibetan-Tethys and Indus suture zones of Zanskar and Ladakh, western Himalaya: Discussion. Journal of Structural Geology, 10, 129-130.

Klootwijk, C.T., Gee, J.S., Peirce, J.W., Smith, G.M. \& McFadden, P.L. 1992. An early India-Asia contact; paleomagnetic constraints from Ninetyeast Ridge, ODP Leg 121. Geology, 20, 395-398.

Meschede, M. 1986. A method of discriminating between different types of mid-ocean ridge basalts and continental tholeiites with the Nb-Zr-Y diagram. Chemical Geology, 56, 207-218.

Moores, E., Roeder, D.H., Abbas, S.G. \& Ahmad, Z. 1980. Geology and emplacement of the Muslim Bagh ophiolite complex. In: Panayiotou, A (ed.) Ophiolites-Proceedings of the international ophiolite symposium, Cyprus 1979. Republic of Cyprus, Ministry of Agriculture and Natural Resources, Geological Survey Department, 424-429.

Patriat, P. \& AChache, J. 1984. India-Eurasia collision chronology has implications for crustal shortening and driving mechanism of plates. Nature, 311, 615-621.

Pearce, J.A. 1996. A Users Guide to Basalt Discrimination Diagrams. In: Wyman, D.A. (ed.) Trace Element Geochemistry of Volcanic Rocks: Applications for Massive Sulphide Exploration. Geological Association of Canada, Short Course Notes, 12, 79-113.

— \& CANN, J.R. 1971. Ophiolite origin investigated by discriminant analysis using Ti, Zr and Y. Earth and Planetary Science Letters, 12, 339-349.

_ \& 1973. Tectonic setting of basic volcanic rocks determined using trace element analyses. Earth and Planetary Science Letters, 19, 290-300. 
Premori Silva, I., Garzanti, E. \& Gaetani, M. 1991. Stratigraphy of the Chikkim and Fatu La formation in the Zangla and Zumlung units (Zanskar Range, India) with comparisons to the Thakkola region (Central Nepal): Mid-Cretaceous evolution of the Indian passive margin. Rivista Italiana di Paleontologia e Stratigrafia, 97, 511-564.

Reibel, G. \& Reuber, I. 1982. La klippe ophiolitique de Spontang-Photoksar (Himalaya du Ladakh); une ophiolite sans cumulats. Compes Rendus de l'academie des Sciences, Paris, 294, 557-562.

Reuber, I. 1986. Geometry of accretion and oceanic thrusting of Spontang Ophiolite, Ladakh-Himalaya. Nature, 321, 592-596.

1989. The Dras Arc: two successive volcanic events on eroded oceanic crust. Tectonophysics, 161, 93-106.

- Colchen, M. \& Mevel, C. 1992. The Spontang Ophiolite and ophiolitic melanges of the Zanskar, N.W. Himalaya, tracing the evolution of the closing Tethys in the upper Cretaceous to the early Tertiary. In: SinHA, A.K. (ed.) Himalayan Orogen and Global Tectonics. Mohan Primlani Ltd, New Dehli, 235-266.

-, Montigny, R., Thuizat, R. \& Heitz, A. 1989. K-Ar ages of ophiolites and arc volcanics of the Indus suture zone: clues on the early evolution of the Neo-Tethys. Eclogae Geologicae Helvetiae, 82, 699-715.

Robertson, A. 1998. Rift-related sedimentation and volcanism of the north Indian margin inferred from a Permian-Triassic exotic block at Lamayuru, Indus suture zone (Ladakh Himalaya) and regional comparisons. Journal of Asian Earth Sciences, 16, 159-172.

\& Degnan, P. 1993. Sedimentology and tectonic implications of the Lamayuru Complex: deep-water facies of the Indian passive margin, Indus Suture Zone, Ladakh Himalaya. In: Treloar, P.J. \& Searle, M.P. (eds) Himalayan Tectonics. Geological Society, London, Special Publications, 74, 299-321.

\& _ 1994. The Dras arc Complex: lithofacies and reconstruction of a late Cretaceous oceanic volcanic arc in the Indus Suture Zone, Ladakh Himalaya. Sedimentary Geology, 92, 117-145.

— \& Sharp, I. 1998. Mesozoic deep-water slope/rise sedimentation and volcanism along the North Indian passive margin: evidence from the Karamba Complex, Indus suture zone (western Ladakh Himalaya). Journal of Asian Earth Sciences, 16, 195-215.

— \& Woodcock, N.H. 1979. Mamonia Complex, Southwest Cyprus; evolution and emplacement of a Mesozoic continental margin. Geological Society of America Bulletin, 90, 651-665.

Schärer, U., Hamet, J. \& Allegre, J. 1984. The Transhimalaya (Gangdese) plutonism in the Ladakh region: a $\mathrm{U}-\mathrm{Pb}$ and $\mathrm{Rb}-\mathrm{Sr}$ study. Earth and Planetary Science Letters, 67, 327-339.

SEARle, M.P. 1983. Stratigraphy, structure and evolution of the Tibetan-Tethys zone in Zanskar and the Indus suture zone in the Ladakh Himalaya. Transactions of the Royal Society of Edinburgh: Earth Sciences, 73, 205-219.
— 1986. Structural evolution and sequence of thrusting in the High Himalayan, Tibetan-Tethys and Indus suture zones of Zanskar and Ladakh, Western Himalaya. Journal of Structural Geology, 8, 923-936.

— \& Cox, J. 1999. Tectonic setting, origin and obduction of the Oman ophiolite. Geological Society of America Bulletin.

- Cooper, D.J.W. \& Rex, A.J. 1988. Collision Tectonics of the Ladakh-Zanskar Himalaya. Philosophical Transactions of the Royal Society, London, A326, 117-150.

- Corfield, R.I., Stephenson, B. \& McCarron, J. 1997. Structure of the North Indian continental margin in the Ladakh-Zanskar Himalayas: Implications for the timing of obduction of the Spontang ophiolite, India-Asia collision and deformation events in the Himalaya. Geological Magazine, 134, 297-316.

—, LipPaRd, S.J., Smewing, J.D. \& ReX, D.C. 1980. Volcanic rocks beneath the Semail ophiolite nappe in the northern Oman mountains and their significance in the Mesozoic evolution of Tethys. Journal of the Geological Society, London, 137, 589-604.

— Pickering, K.T. \& Cooper, D.J.W. 1990. Restoration and evolution of the intermontane Indus molasse basin, Ladakh Himalaya, India. Tectonophysics, 174, 301-314.

—, Windley, B.F., Coward, M.P., Cooper, D.J.W., ReX, A.J., ReX, D., Li, Tingdong, Xiao, Xuchang, Jan, M.Q., Thakur, V.C. \& Kumar, S. 1987. The closing of Tethys and the tectonics of the Himalaya. Geological Society of America Bulletin, 98, 678-701.

Shervais, J.W. 1982. Ti-V plots and the petrogenesis of modern and ophiolitic lavas. Earth and Planetary Science Letters, 59, 101-118.

SRIKANTIA, S.V. \& RAZDAN, M.L. 1981. Shilakong ophiolite nappe of Zanskar mountains, Ladakh Himalaya. Journal of the Geological Society of India 22, 227-234.

THAKUR, V.C. 1981. Regional framework and geodynamic evolution of the Indus-Tsangpo suture zone in the Ladakh Himalaya. Transactions of the Royal Society of Edinburgh: Earth Sciences, 72, 89-97.

Treloar, P.J., Petterson, M.G., Jan, M.Q. \& Sullivan, M.A. 1996. A re-evaluation of the stratigraphy and evolution of the Kohistan Arc sequence, Pakistan Himalaya: implications for magmatic and tectonic arc-building processes. Journal of the Geological Society, London, 153, 681-693.

Winchester, J.A. \& Floyd, P.A. 1977. Geochemical discrimination of different magma series and their differentiation products using immobile elements. Chemical Geology, 20, 325-343.

—, Park, R.G. \& Holland, J.G. 1980. The geochemistry of Lewisian semipelitic schists from the Gairloch District, Wester Ross. Scottish Journal of Geology, 16, 165-179.

Wood, D.A., Joron, J.L. \& Treuil, M. 1979. A re-appraisal of the use of trace elements to classify and discriminate between magma series erupted in different tectonic settings. Earth and Planetary Science Letters, 45, 326-336. 